Eur J Clin Chem Clin Biochem

1995; 33:73-81

(c) 1995 Walter de Gruyter \& Co.

Berlin - New York

\title{
Cryopreservation and Long-Term Storage of Human Low Density Lipoproteins
}

\author{
By Alexander B. Sigalov \\ Biomedical Department, AMW Co Ltd., Moscow, Russia
}

(Received July 22/October 18, 1994)

\begin{abstract}
Summary: A simple and effective technique of long-term storage of human low density lipoproteins (LDL) has been developed. The technique involves the addition of $1.4 \mathrm{~mol} / 1$ (or $10 \%$ by volume) dimethyl sulphoxide directly to a solution of the freshly isolated LDL in high salt buffer, and subsequent freezing and storage for up to 2 years at $-70^{\circ} \mathrm{C}$. We have shown that freshly isolated LDL, "preserved" as described above, are able to keep their native properties for a long period, i. e.:

a) electrophoretic behaviour in non-denaturing (or with sodium dodecyl sulphate, $1 \mathrm{~g} / \mathrm{l}$ ) polyacrylamide $2-16 \%$ gradient gel electrophoresis;

b) immunoreactivity of apolipoprotein B (analyzed by radial immunodiffusion, electroimmunoassay and immunoturbidimetric assay);

c) immunogeneity of apolipoprotein B;

d) an average size of LDL particles (analyzed by electron microscopy);

e) ability to bind with B,E-receptors of human skin fibroblasts.
\end{abstract}

The technique can also be applied to radiolabelled LDL samples. Taking into consideration the labour- and timeconsuming procedure of obtaining and characterizing LDL, and the preferred use of single well-characterized LDL preparation, we recommend that the above technique of LDL long-term storage be applied in various clinical and biomedical studies.

\section{Introduction}

Low density lipoproteins (LDL) play a key role in the transport of cholesterol to the periphera! tissues where they are bound to cellular receptors and ingested by endocytosis (1). LDL also play an important role in the pathological uptake and deposition of cholesterol since very high concentrations of LDL are implicated as the causative agent of some forms of human atherosclerosis, while moderate elevations over long periods of time may be an important factor in the development of most human atherosclerosis $(2,3)$. Therefore, LDL themselves and their B,E-receptor binding ability are widely studied (4-8). Furthermore, purified LDL preparations are also used to obtain poly- and monoclonal antibodies $(9-10)$, as well as a primary standard for apolipoprotein B measurements by immunochemical assays (11). Traditionally, only fresh LDL are used for these purposes. It necessitates a large number of repeated technical operations to obtain and characterize LDL (particularly, when LDL are used as an immunogen and as a primary standard). Hence, an investigator is not able to compare within one long-term experiment the properties of LDL obtained by different methods and time.

Recently, it has been shown that sucrose can be used as a cryoprotector for a long-term storage of the isolated LDL at low temperature (12). On the other hand, there 
exist widely known techniques of human and animal cells long-term storage by freezing them in the presence of liquid cryoprotectors (dimethyl sulphoxide, glycerol and etc.) and keeping them at $-70^{\circ} \mathrm{C}$ or, preferably, in liquid nitrogen $(13-14)$.

In this work we suggest a simple and effective technique of long-term LDL storage at $-70^{\circ} \mathrm{C}$ by freezing them in the presence of $1.4 \mathrm{~mol} / \mathrm{l}(10 \%$ by volume) dimethyl sulphoxide. It is shown that this storage method does not cause the loss of the native properties of LDL by using them as an immunogen for obtaining the polyclonal monospecific sheep's antiserum, as a primary standard for apolipoprotein B measurements by immunochemical assays and as a ligand. The data reported here have been obtained as a result of two-year experiments.

\section{Materials and Methods}

Reagents

Phenyl methylsulphonyl fluoride, sodium bromide, and dimethyl sulphoxide were obtained from Merck (Darmstadt, Germany). Carrier-free $\mathrm{Na}^{125} \mathrm{I}$ was obtained from Amersham (Arlington Heigts, IL). Reagents for polyacrylamide gel electrophoresis were from Serva (Heidelberg, Germany). Horseradish peroxidase (EC 1.11.1.7) and peroxidase substrate (3,3'-diaminobenzidine) were obtained from Sigma Chemical Company (St. Louis, MO).

The candidate international standard plasma pool for apolipoprotein quantitation No. 1883 was obtained from the Centers for Disease Control (Atlanta, Georgia). A reference serum (Lot No. $063511)$ with assigned values for apolipoprotein A-I $(1.62 \mathrm{~g} / \mathrm{l})$ and apolipoprotein B $(1.21 \mathrm{~g} / \mathrm{l})$ was obtained from Behringwerke AG (Marburg, Germany).

\section{Collection of specimens}

Blood was collected from hyperlipidaemic and normolipidaemic individuals by venipucture into Vacutainer tubes (Becton-Dickinson, Rutherford, NJ) in the absence of ethylenediamine-tetraacetate, following a $12-14 \mathrm{~h}$ fast, and pooled. Upon separation at $4{ }^{\circ} \mathrm{C}$ by low-speed centrifugation, the serum was prepared for the immediate isolation of low density lipoprotein fraction. Disodium ethylenediamine-tetraacetate, sodium azide, and phenyl methylsulphonyl fluoride were added to final concentration of $1 \mathrm{mmol} / 1,0.2 \mathrm{~g} / \mathrm{l}$, and $1 \mathrm{mmol} / \mathrm{l}$, respectively.

\section{Isolation and characterization of $\mathrm{LDL}$}

LDL (d $1.030-1.050 \mathrm{~kg} / \mathrm{l}$ ) was isolated from pooled serum of individuals by sequential ultracentrifugation as previously described (15) in a L8-70 ultracentrifuge (Beckman Instruments, Paolo Alto, U.S.A.) using $45 \mathrm{Ti}$ rotor with potassium bromide being substituted for sodium bromide. Immediately after recentrifugation at d $1.050 \mathrm{~kg} / \mathrm{l}$, the LDL fraction was filtered through a filter stack of glassfibre prefilter and 0.2 micron filter (Sartorius $\mathrm{GmbH}$, Goettingen, Germany) under sterile conditions. LDL purity was assessed by $1 \mathrm{~g} / \mathrm{l}$ sodium dodecyl sulfate, $2-16 \%$ gradient polyacrylamide gel electrophoresis (16) and by Ouchterlony's method (17) with Calbiochem Corp. (San Diego, CA) anti-apolipoprotein A-I, anti-apolipoprotein A-II and anti-apolipoprotein $\mathrm{E}$ antibodies, and with home-made anti-apolipoprotein $\mathrm{B}$ antibodies.
Total LDL protein concentration was determined by the method of Lowry et al. (18) as modified by Albers et al. (19). A standard curve was prepared by diluting the bovine plasma albumin standard II ( $1.37 \mathrm{~g} / \mathrm{l}$, Lot No. 34522, Bio-Rad Laboratories, Richmond, CA) to $0.046,0.091,0.137$, and $0.228 \mathrm{~g} / \mathrm{l}$ in $0.15 \mathrm{~mol} / 1$ sodium chloride. Samples were diluted with $0.15 \mathrm{~mol} / 1$ sodium chloride to three different concentrations within the working range.

Total cholesterol, unesterified cholesterol and triacylglycerols were measured by enzymatic methods using Boehringer (Mannheim, Germany) reagents. Phospholipids were determined as phosphorus (20) using an average relative molecular mass of $M_{\mathrm{r}}=775$ for phospholipid.

LDL used in receptor-binding studies was radiolabelled with ${ }^{125}$ I using the iodine monochloride procedure of McFarlane (21) as modified by Bilheimer et al. (22). The specific radioactivity of the apolipoprotein B-100 was about 400 counts/min $\cdot \mathrm{ng}$ of protein, and over $97 \%$ of the radioactivity was precipitable by incubation with $100 \mathrm{~g} / \mathrm{l}$ trichloroacetic acid solution at $4^{\circ} \mathrm{C}$.

Lipoprotein-deficient serum was obtained by double ultracentrifugation of the freshly pooled serum of healthy donors with a density of $1.25 \mathrm{~kg} / \mathrm{l}$ for $48 \mathrm{~h}$ at $105000 \mathrm{~g}$. After centrifugation, the serum was dialyzed against $0.15 \mathrm{~mol} / \mathrm{l}$ sodium chloride, sterilized by filtration (Sartorius filters, $0.2 \mu \mathrm{m}$ ), frozen, and stored at $-40^{\circ} \mathrm{C}$. The concentration of apolipoprotein B-containing lipoproteins in the lipoprotein-deficient serum did not exceed $0.1 \mathrm{mg} / \mathrm{l}$.

Preparation of antiserum and antibody-enzyme conjugate

Isolated LDL was used to prepare anti-apolipoprotein B antiserum by immunization in sheeps as previously described (23). The specifity of the antisera obtained was assessed by double radial immunodiffusion and two-dimensional immunoelectrophoresis with homemade apolipoprotein A-I, apolipoprotein A-II, apolipoprotein E, apolipoprotein C's, apolipoprotein E, apolipoprotein(a), and with lipoprotein-deficient serum. The IgG fraction for Western blotting was obtained by precipitation with saturated ammonium sulphate as described (24). Rabbit anti-sheep IgG antibodies were conjugated with horseradish peroxidase as previously described (24).

\section{Cryopreservation and storage of LDL}

Each LDL preparation was divided into $16-18$ portions $(0.3 \mathrm{ml})$. $33 \mu \mathrm{l}$ of dimethyl sulphoxide per $0.3 \mathrm{ml}$ ( $10 \%$ by volume) was added to the first $12-14$ portions and $33 \mu \mathrm{l}$ of sodium chloride/ sodium bromide solution with the density $1.05 \mathrm{~kg} / \mathrm{l}$ per $0.3 \mathrm{ml}$ ( $10 \%$ by volume) was added to the remaining four portions which were used as controls. Both dimethyl sulphoxide and sodium chloride/sodium bromide solution with the density $1.05 \mathrm{~kg} / \mathrm{l}$ were previously filtered through a filter stack of glassfibre prefilter and 0.2 micron filter (Sartorius GmbH, Göttingen, Germany) under sterile conditions. Two from four control portions were stored at $4^{\circ} \mathrm{C}$. Two other control portions and the portions of the LDL with dimethyl sulphoxide were placed into a foam plastic container with a wall thickness of $2 \mathrm{~cm}$ and slowly freezed (about $1 .{ }^{\circ} \mathrm{C}$ per min) in the ultra low freezer (Sanyo, Japan) at $-70^{\circ} \mathrm{C}$ as recommended for preservation of human or animal cells $(13,14)$. Immediately before the use, the LDL portions were quickly defrosted at $37^{\circ} \mathrm{C}$.

\section{Polyacrylamide gradient gel electrophoresis}

The apolipoprotein B fragmentation was studied on home-made slab $2-16 \%$ polyacrylamide linear gradient gels containing $1 \mathrm{~g} / \mathrm{l}$ sodium dodecyl sulphate (16): The samples were heated for $5 \mathrm{~min}$ at $100^{\circ} \mathrm{C}$ in $50 \mathrm{mmol} / \mathrm{l} \mathrm{Tris,} \mathrm{pH} 6.8,30 \mathrm{~g} / \mathrm{l}$ sodium dodecyl sulphate, $200 \mathrm{~g} / \mathrm{l}$ glycerol, $50 \mathrm{~g} / 1$ 2-mercaptoethanol. The electrophoresis was carried out at $20 \mathrm{~mA}$ for $20 \mathrm{~h}$. The proteins were either stained with Coomassie Blue R-250 or transferred to nitrocellulose paper (see below). is 
Non-denaturing gradient polyacrylamide gel electrophoresis of LDL was done on Pharmacia Electrophoresis Apparatus (GE 2/4) using home-made slab 2-16\% polyacrylamide linear gradient gels in $14 \mathrm{mmol} / 1$ Tris, $110 \mathrm{mmol} / 1$ glycine, $0.1 \mathrm{~g} / \mathrm{l}$ sodium azide, $\mathrm{pH}$ 8.3, as described by Krauss \& Burke (25). The gels were prerun $30 \mathrm{~min}$ at $50 \mathrm{~V}$. Routinely, the samples containing $15 \mu \mathrm{g}$ of protein were applied to each sample well. Electrophoresis was started at $30 \mathrm{~V}$ for $1 \mathrm{~h}$ and continued for $20 \mathrm{~h}$ at $80 \mathrm{~V}$. Gels were stained with Coomassie Blue R-250 for protein. In some cases LDL samples were prestained with acetylated Sudan Black B. Unstained gels were used for immunoblotting techniques.

\section{Immunoblotting}

After electrophoresis, the LDL particles were blotted (26) to nitrocellulose paper $(0.45 \mu \mathrm{m}$, Serva, Heidelberg, Germany) by the electrophoretic transfer of the gel in the electrophoretic buffer at $100 \mathrm{~mA}$ for up to $72 \mathrm{~h}$ at $4^{\circ} \mathrm{C}$. All additional operations were performed as described (27).

\section{Immunochemical assays}

Single radial immunodiffusion was performed with commercially available M-Partigen-Apolipoprotein B plates from Behringwerke AG (Marburg, Germany) according to the manufacturer's instructions for maximal diffusion time of $96 \mathrm{~h}$ at $37^{\circ} \mathrm{C}$. Electroimmunoassay was performed by the method of Laurell (28) using $10 \mathrm{~g} / 1$ agarose (Sigma Chemical Company, St. Louis, MO), containing 15 $\mathrm{g} / \mathrm{l}$ antiserum to human apolipoprotein B. The LDL samples were diluted to three different concentrations within the working range. All subsequent operations were performed as described (29). Apolipoprotein $B$ values in the LDL samples were also determined by the immunoturbidimetric assay as described (30) with some modifications. Briefly, the LDL samples were diluted to three different concentrations with phosphate-buffered saline (per litre: $9 \mathrm{~g}$ of sodium chloride, $10 \mathrm{mmol}$ of monopotassium phosphate, $\mathrm{pH}$ 7.4) within the working range $(0.3-2.5 \mathrm{~g} / \mathrm{l})$. Antiserum was diluted 10fold in phosphate-buffered saline containing $40 \mathrm{~g}$ of polyethylene glycol 6000 (Serva, Heidelberg, Germany) per litre and preincubated for $30 \mathrm{~min}$ at $20-25^{\circ} \mathrm{C}$. Then, $25 \mu 1$ of diluted LDL was added to $750 \mu \mathrm{l}$ of diluted antiserum. Samples were vortexed, incubated at $20-25^{\circ} \mathrm{C}$ for $60 \mathrm{~min}$, vortexed again and the changes in turbidity of the samples against a reagent blank (mixture of $25 \mu \mathrm{l}$ of sample diluent and $750 \mu \mathrm{l}$ of diluted antiserum) were measured at $340 \mathrm{~nm}$ using a Spectronic 2000 spectrophotometer (Bausch \& Lomb, Rochester, New York). A standard curve generated by leastsquares linear regression analysis was used to calculate the concentrations of the unknowns.

Standards, quality controls and samples were analyzed in triplicate in all immunochemical, protein, and lipid assays.

\section{Cells}

Human skin fibroblasts (6th-10th passages) were grown from forearm skin biopsies of healthy donors. The cells were cultured at $37^{\circ} \mathrm{C}$ in an atmosphere of $5 \% \mathrm{CO}_{2} / 95 \%$ air in plastic flasks with Eagles's minimum essential medium containing $25 \mathrm{mmol} / \mathrm{l}$ Hepes, $220 \mathrm{mmol} / \mathrm{l}$ sodium bicarbonate, $10 \mathrm{~g} / \mathrm{l}$ non-essential amino acids, $100 \mathrm{mg} / \mathrm{l}$ canamycin, $2 \mathrm{mmol} / \mathrm{l}$ glutamine, and $150 \mathrm{~g} / \mathrm{l}$ fetal calf serum (medium A). The cells were then plated onto $60-\mathrm{mm}$ Petri dishes at a cell density of $1 \times 10^{5}$ cells per dish. Three or four days later, the cells were washed with phosphate-buffered saline and the medium of the same composition as medium $A$ but containing $100 \mathrm{~g} / 1$ lipoprotein-deficient serum instead of fetal calf serum (medium B) was added and cells were incubated for $48 \mathrm{~h}$.

\section{Measurements of LDL binding, internalization and} degradation

The amount of surface-bound ${ }^{125} \mathrm{I}$-labelled LDL, and intracellular ${ }^{125}$ I-labelled LDL was measured in intact fibroblast monolayers essentially as described by Goldstein, Basu \& Brown (8). Typically, after incubating the cells at $37^{\circ} \mathrm{C}$ for $3 \mathrm{~h}$ in the presence of various amounts of ${ }^{125} \mathrm{I}$-labelled LDL $\left(5,10\right.$ or $20 \mathrm{mg} / \mathrm{l}$ of [ $\left.{ }^{125} \mathrm{I}\right] \mathrm{LDL}$ protein) for the specific binding, and ${ }^{125}$ I-labelled LDL and a 20 -fold excess of unlabelled LDL for the non-specific binding, cell monolayers were washed at $4{ }^{\circ} \mathrm{C} 5$ times with phosphate-buffered saline containing $2 \mathrm{~g} / \mathrm{l}$ bovine serum albumin and twice with buffer without bovine serum albumin. The cells were then incubated for $1 \mathrm{~h}$ with $2 \mathrm{ml}$ of the medium $\mathrm{B}$, containing dextran sulphate $(10 \mathrm{~g} / \mathrm{l})$, at $4{ }^{\circ} \mathrm{C}$ with shaking. The amount of LDL bound was determined from the dextran sulphate-releasable radioactivity in the medium. The cells were then washed and dissolved in $100 \mathrm{mmol} / \mathrm{l}$ sodium hydroxide for determination of LDL internalization and protein content. LDL degradation was determined as the difference between the amount of non-iodine, non-lipid trichloroacetic acid-soluble radioactivity in the medium and the amount due to spontaneous degradation. The latter was measured in duplicate incubations with no cells present in the system.

\section{Electron microscopy}

Samples of LDL were negatively stained with $20 \mathrm{~g} / \mathrm{l}$ sodium phosphotungstate ( $\mathrm{pH} 7.4)$ and immediately examined in the electron microscope as previously described (31).

\section{Results}

\section{Electrophoretic investigations}

The data of non-denaturing $2-16 \%$ gradient polyacrylamide gel electrophoresis show that by the storage of freshly isolated LDL ("fresh" LDL) within $40-60$ days at $4{ }^{\circ} \mathrm{C}$ particles were formed, having less electrophoretical mobility, well stained by Sudan Black, Coomassie Blue R-250 and interacting with sheep anti-human apolipoprotein B antibodies by immunostaining (see fig. 1, $A-C$, lane 2). The samples of the same LDL, containing $1.4 \mathrm{~mol} / \mathrm{l}$ dimethyl sulphoxide and freezed as described in Materials and Methods ("preserved" LDL) after 2 years of storage at $-70^{\circ} \mathrm{C}$ did not contain such particles (see fig. 1, A-C, lane 3) and had an electrophoretical pattern similar to freshly isolated LDL (see fig. $1, \mathrm{~A}-\mathrm{C}$, lane 1). The freezing and subsequent storage at $-70^{\circ} \mathrm{C}$ within 2 years of the same LDL not containing dimethyl sulphoxide ("control" LDL) led to the formation of particles migrating significantly slower than LDL (see fig. 1, A-C, lane 4) and having similar abilities to be stained by Sudan Black, Coomassie Blue R-250 and interact with sheep anti-human apolipoprotein $\mathrm{B}$ antibodies as compared with particles formed under long-term storage of LDL at $4{ }^{\circ} \mathrm{C}$. It is obvious that the particles formed in both cases are aggregated LDL.

To examine probable apolipoprotein B fragmentation we have analyzed the samples of freshly isolated LDL, "fresh", "preserved" and "control" LDL (the latter two - after two-year storage at $-70^{\circ} \mathrm{C}$ ) by $2-16 \%$ gradient polyacrylamide gel electrophoresis in the presence of $1 \mathrm{~g} / \mathrm{l}$ sodium dodecyl sulphate with the subsequent immunoblottings as described in Materials and Methods. 


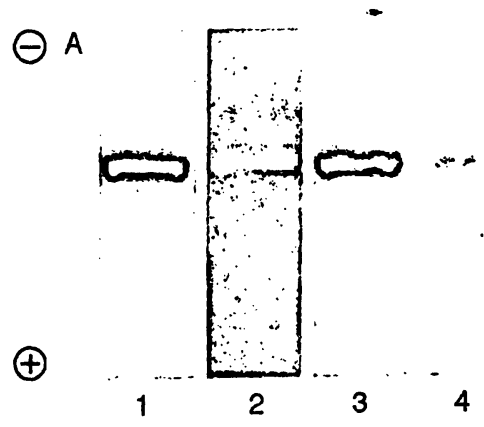

Fig. 1 Non-denaturing 2-16\% gradient polyacrylamide gel electrophoresis of: freshly isolated LDL (A-C, line 1), "fresh" LDL - stored for 2 months at $4^{\circ} \mathrm{C}(\mathrm{A}-\mathrm{C}$, lane 2), "preserved" LDL - frozen in the presence of $1.4 \mathrm{~mol} / /$ dimethyl sulphoxide and subsequently stored for 2 years at $-70^{\circ} \mathrm{C}(\mathrm{A}-\mathrm{C}$, lane 3$)$, "control" LDL - frozen without dimethyl sulphoxide and subsequently stored for 2 years at $-70^{\circ} \mathrm{C}(\mathrm{A}-\mathrm{C}$, lane 4). Twenty $\mu \mathrm{g}$ of $\mathrm{LDL}$

The data obtained show no significant differences between the analyzed samples and no apolipoprotein B fragmentation (data not shown).

Similar results were obtained for three different LDL preparations. Hence the given data prove that the freezing of freshly isolated native LDL in the presence of 1.4 $\mathrm{mol} / \mathrm{l}$ dimethyl sulphoxide and their subsequent storage at $-70^{\circ} \mathrm{C}$ for two-year period did not cause any significant changes in electrophoretic pattern.

In addition, it has been demonstrated by non-denaturing $2-16 \%$ gradient polyacrylamide gel electrophoresis that freezing and subsequent thawing of the "preserved" LDL according to the procedure described in Materials and Methods did not cause changes in electrophoretic pattern even after three-fold repetition. In contrast, the freeze-thawing of "control" LDL (not containing dimethyl sulphoxide) led to the formation of aggregated LDL, whereas the aggregation degree was highly dependent on the number of freeze-thawing cycles. The gels were stained by Sudan Black; similar results were obtained by staining by Coomassie Blue R-250 (data not shown). Thus, the given data indicate a certain antiaggregatory effect of dimethyl sulphoxide on LDL even after three-fold repetition of freeze-thawing procedure.

To study the effect of freezing and subsequent storage in the presence of dimethyl sulphoxide upon the electrophoretic pattern of radiolabelled LDL, the fresh LDL sample was radiolabelled with ${ }^{125}$ I as described in Materials and Methods. One portion was subsequently frozen in the presence of $1.4 \mathrm{~mol} / \mathrm{l}$ dimethyl sulphoxide and stored at $-70^{\circ} \mathrm{C}$ within 7 days ("preserved" [ $\left.{ }^{125} \mathrm{I}\right] \mathrm{LDL}$ ), whereas another one was stored at $4{ }^{\circ} \mathrm{C}$ ("freshly isolated" [ $\left.\left.{ }^{125} \mathrm{I}\right] \mathrm{LDL}\right)$. Equal aliquots of both "freshly isolated" and "preserved" [ ${ }^{125}$ I] LDL were analyzed by nondenaturing $2-16 \%$ gradient polyacrylamide gel electrophoresis as described in Materials and Methods. After electrophoresis, the LDL particles were stained by Coomassie R-250 or transferred to nitrocellulose paper as described in Materials and Methods. After drying, autoradiography was performed at $4{ }^{\circ} \mathrm{C}$ using an intensifying screen for $10 \mathrm{~min}$. No differences were found in the electrophoretic patterns for both "freshly isolated", and "preserved" [ $\left.{ }^{125} I\right] L D L$ samples.

\section{Lipid and protein composition}

To study the impact of freezing and subsequent storage in the presence of dimethyl sulphoxide upon the LDL lipid and protein content, we compared the results (for three various LDL preparations - LDL1, LDL2, LDL3) of the total and free cholesterol, phospholipid, triacylglycerol and protein determinations, obtained immediately after LDL isolation ("freshly isolated" LDL), and after freezing with $1.4 \mathrm{~mol} / \mathrm{l}$ dimethyl sulphoxide as described in Materials and Methods, and subsequent storage for 2 years at $-70^{\circ} \mathrm{C}$ ("preserved" LDL). Table 1 shows that there is no significant difference between the three cases.

Thus, freezing LDL in the presence of dimethyl sulphoxide and subsequent long-term storage at $-70^{\circ} \mathrm{C}$ have no effect on the results of the LDL lipid and protein determinations.

\section{Immunogeneity of LDL}

The LDL samples frozen in the presence of dimethyl sulphoxide ("preserved" LDL) after various periods (from 1 month up to 2 years) of storage at $-70^{\circ} \mathrm{C}$ were used as an antigen to obtain polyclonal sheep antisera against apolipoprotein $\mathrm{B}$. The analysis of specificity by double radial immunodiffusion and two-dimension immunoelectrophoresis shows that there is no difference between the above antisera and the one obtained by 
Tab. 1 Effect of LDL freezing with $1.4 \mathrm{~mol} / \mathrm{l}$ dimethyl sulphoxide and subsequent storage at $-70^{\circ} \mathrm{C}$ on lipid and protein quantitation ${ }^{\mathrm{a}}$.

\begin{tabular}{|c|c|c|c|c|c|c|c|}
\hline \multirow[t]{3}{*}{ Analyte } & \multirow{3}{*}{$\therefore$} & \multicolumn{6}{|c|}{ Concentration of analyte, $\mathrm{g} / \mathrm{l}$} \\
\hline & & \multicolumn{2}{|l|}{ LDL1 } & \multicolumn{2}{|l|}{ LDL2 } & \multicolumn{2}{|l|}{ LDL3 } \\
\hline & & $\begin{array}{l}\text { freshly } \\
\text { isolated }\end{array}$ & preserved & $\begin{array}{l}\text { freshly } \\
\text { isolated }\end{array}$ & preserved & $\begin{array}{l}\text { freshly } \\
\text { isolated }\end{array}$ & preserved \\
\hline Total cholesterol & & $38.3 \pm 0.4$ & $38.1 \pm 0.8$ & $22.6 \pm 0.5$ & $22.8 \pm 0.4$ & $34.8 \pm 0.4$ & $35.0 \pm 0.5$ \\
\hline Free cholesterol & & $10.8 \pm 0.3$ & $10.9 \pm 0.3$ & $6.3 \pm 0.3$ & $6.4 \pm 0.3$ & $10.7 \pm 0.4$ & $10.8 \pm 0.4$ \\
\hline Triacyglycerols & & $6.1 \pm 0.2$ & $6.2 \pm 0.2$ & $3.9 \pm 0.1$ & $3.8 \pm 0.1$ & $5.9 \pm 0.2$ & $6.0 \pm 0.2$ \\
\hline Phospholipid & & $22.3 \pm 0.6$ & $22.6 \pm 0.7$ & $14.6 \pm 0.5$ & $14.4 \pm 0.4$ & $23.8 \pm 0.6$ & $23.6 \pm 0$ \\
\hline Protein & & $23.5 \pm 0.7$ & $23.7 \pm 0.5$ & $13.4 \pm 0.4$ & $13.6 \pm 0.4$ & $22.0 \pm 0.5$ & $22.1 \pm 0.5$ \\
\hline
\end{tabular}

a Three LDL preparations (LDL1, LDL2 and LDL3) were obtained as described in Materials and Methods. Aliquots of LDL were assessed for lipid and protein content immediately after isolation ("freshly isolated") and after freezing and subsequent

freshly isolated LDL. The titre determination by an immunoturbidimetric assay (approximately $0.5 \mathrm{~g} / \mathrm{l}$ ) also showed no significant differences between the antisera. We later successfully used the antisera obtained with "preserved" LDL in kits for immunoturbidimetric apolipoprotein $\mathrm{B}$ determination in human sera by mass screening.

Hence the LDL freezing in the presence of dimethyl sulphoxide and subsequent long-term storage at $-70^{\circ} \mathrm{C}$ do not exert significant effects upon LDL immunogenic properties.

\section{Apolipoprotein B immunoreactivity}

To study the influence of the freezing and storage procedures upon the apolipoprotein B immunoreactivity, we have performed apolipoprotein B analysis of two different LDL preparations (LDL1 and LDL2) by three immunoprecipitin methods: single radial immunodiffusion, electroimmunoassay and immunoturbidimetric assay. LDL samples were analyzed immediately after isolation ("freshly isolated" LDL), after freezing and storage for up to 2 years at $-70^{\circ} \mathrm{C}$ both in the presence of 1.4 mol/l dimethyl sulphoxide ("preserved" LDL) and in the absence of dimethyl sulphoxide ("control" LDL). As shown in table 2 the results of the apolipoprotein B determination by three analytical methods in "freshly isolated" LDL and in "preserved" LDL did not differ significantly (at $p>0.01$ ) between both LDL preparations (LDL1 and LDL2). In contrast, the apolipoprotein B values in "control" LDL determined by "gel" techniques (single radial immunodiffusion and electroimmunoassay) significantly differ (at $p<0.01$ ) from the ones for "freshly isolated" and "preserved" LDL. Depending upon the method (single radial immunodiffusion or electroimmunoassay) the difference ranged from 16- storage in the presence of $1.4 \mathrm{~mol} / 1$ dimethyl sulphoxide for 2 years at $-70^{\circ} \mathrm{C}$ ("preserved"). All values are means $\pm \mathrm{SD}$ from triplicate determinations.

$23 \%$. A similar difference was not observed for immunoturbidimetric assay (see tab. 2).

Thus, freezing with $1.4 \mathrm{~mol} / \mathrm{l}$ dimethyl sulphoxide and subsequent storage of $\mathrm{LDL}$ for up to 2 years at $-70^{\circ} \mathrm{C}$ do not effect the apolipoprotein $\mathrm{B}$ immunoreactivity, at least in the three immunoassays used.

\section{Cell studies}

To study the effect of LDL freezing with $1.4 \mathrm{~mol} / \mathrm{l}$ dimethyl sulphoxide and subsequent storage upon the LDL-receptor activity, equal aliquots of "freshly isolated" and "preserved" [ $\left.{ }^{125} \mathrm{I}\right] \mathrm{LDL}$ were used in the experiments to measure the specific binding, internalization and degradation of LDL by fibroblasts as described in Materials and Methods. As shown in table 3 the values of specific binding, internalization and degradation of LDL by fibroblasts did not significantly (at $\mathrm{p}>0.01$ ) differ for "freshly isolated" and "preserved" $\left[{ }^{125} I\right] \mathrm{LDL}$, thus indicating the absence of a considerable effect of the $\left[{ }^{125} \mathrm{I}\right] \mathrm{LDL}$ freezing and storage in the presence of $1.4 \mathrm{~mol} / \mathrm{l}$ dimethyl sulphoxide on LDL-receptor activity.

\section{Electron microscopy}

To study the effect of freezing and storage in the presence of dimethyl sulphoxide upon the LDL morphologic properties, one of the two aliquots of LDL was examined in the electron microscope within 1 week after isolation, and the second one after freezing with $1.4 \mathrm{~mol} / \mathrm{l}$ dimethyl sulphoxide as described in Materials and Methods, and subsequent storage for 2 years at $-70^{\circ} \mathrm{C}$ (data not shown). The particles in both samples appeared to be relatively uniform in size. In both cases the average size of particles was $22 \pm 2 \mathrm{~nm}$, which was in 
Tab. 2 Effect of LDL freezing with $\% 1.4 \mathrm{~mol} / \mathrm{l}$ dimethyl sulphoxide and subsequent storage at $-70^{\circ} \mathrm{C}$ on apolipoprotein $\mathrm{B}$ quantitation by immunoprecipitin methods $\mathrm{s}^{\mathrm{a}}$.

\begin{tabular}{|c|c|c|c|c|c|c|}
\hline \multirow[t]{3}{*}{ Method } & \multicolumn{6}{|c|}{ Concentration of apolipoprotein B, g/l } \\
\hline & \multicolumn{3}{|l|}{ LDLI } & \multicolumn{3}{|l|}{ LDL2 } \\
\hline & $\begin{array}{l}\text { freshly } \\
\text { isolated }\end{array}$ & preserved & control & $\begin{array}{l}\text { freshly } \\
\text { isolated }\end{array}$ & prèserved & control \\
\hline $\begin{array}{l}\text { Radial immunodiffusion } \\
\text { Electroimmunoassay } \\
\text { Immunoturbidimetric assay }\end{array}$ & $\begin{array}{l}23.4 \pm 0.8 \\
23.8 \pm 0.7 \\
23.6 \pm 1.0\end{array}$ & $\begin{array}{l}23.6 \pm 0.6 \\
24.2 \pm 1.0 \\
23.5 \pm 0.8\end{array}$ & $\begin{array}{l}19.7 \pm 0.7 \\
18.4 \pm 0.8 \\
23.2 \pm 0.8\end{array}$ & $\begin{array}{l}13.7 \pm 0.5 \\
13.7 \pm 0.4 \\
13.8 \pm 0.3\end{array}$ & $\begin{array}{l}13.4 \pm 0.5 \\
13.4 \pm 0.4 \\
13.9 \pm 0.3\end{array}$ & $\begin{array}{l}11.3 \pm 0.6 \\
10.4 \pm 0.3 \\
13.9 \pm 0.3\end{array}$ \\
\hline
\end{tabular}

a Tivo LDL preparations (LDL1 and LDL2) were obtained as described in Materials and Methods. Aliquots of LDL were assessed for apolipoprotein B content immediately after isolation ("freshly isolated") and after freezing and subsequent storage for
2 years at $-70^{\circ} \mathrm{C}$ in the presence ("preserved") or in the absence ("control") of $1.4 \mathrm{~mol} / \mathrm{l}$ dimethyl sulphoxide. All values are means \pm SD from triplicate determinations.
Tab. 3 Comparison of "freshly isolated" and "preserved" [25l]LDL (freezing with $1.4 \mathrm{~mol} / 1$ dimethyl sulphoxide and subse- quent storage for 7 days at $-70^{\circ} \mathrm{C}$ ) specific binding by human skin fibroblasts $\mathrm{s}^{\mathrm{a}}$, internalization and degradation at $37^{\circ} \mathrm{C}$.

\begin{tabular}{|c|c|c|c|}
\hline \multirow[t]{2}{*}{ Lipoprotein } & \multicolumn{3}{|c|}{$\mathrm{ng}$ of ${ }^{125}$ I-labelled lipoprotein per $\mathrm{mg}$ cell protein } \\
\hline & Binding & Internalization & Degradation \\
\hline \multicolumn{4}{|c|}{ Freshly isolated $\left[{ }^{125} \mathrm{I}\right] \mathrm{LDL}$} \\
\hline $\begin{array}{l}10 \mathrm{mg} / \mathrm{h} \\
20 \mathrm{mg} / \mathrm{l}\end{array}$ & $\begin{array}{r}75.0 \pm 1.2 \\
149.7 \pm 3.1\end{array}$ & $\begin{array}{r}679.8 \pm 8.3 \\
1109.5 \pm 26.2\end{array}$ & $\begin{array}{l}1026.4 \pm 28.5 \\
1734.8 \pm 36.3 .5\end{array}$ \\
\hline \multicolumn{4}{|c|}{ Preserved $\left[{ }^{125} \mathrm{I}\right] \mathrm{LDL}$} \\
\hline $\begin{array}{l}10 \mathrm{mg} / 1 \\
20 \mathrm{mg} / \mathrm{l}\end{array}$ & $\begin{array}{r}76.9 \pm 2.1 \\
146.9 \pm 2.3\end{array}$ & $\begin{array}{r}683.4 \pm 9.8 \\
1124.8 \pm 22.1\end{array}$ & $\begin{array}{l}1013.7 \pm 25.6 \\
1716.6 \pm 33.7\end{array}$ \\
\hline
\end{tabular}

a Human fibroblasts were incubated for $3 \mathrm{~h}$ at $37^{\circ} \mathrm{C}$ with the indicated concentrations of radiolabelled lipoproteins. The binding, internalization and degradation were determined as described in Materials and Methods and were corrected for non-specific bind-

ing, internalization and degradation in the presence of 20 -fold excess of unlabelled human LDL. All values are means \pm SD from triplicate determinations.

agreement with reported data on particle sizes of such LDL subfraction (31).

Thus, the LDL freezing in the presence of $1.4 \mathrm{~mol} / \mathrm{l} \mathrm{di}-$ methyl sulphoxide and their subsequent storage for up to 2 years at $-70^{\circ} \mathrm{C}$ do not lead to an obvious alteration of morphologic LDL properties.

\section{Discussion}

In a majority of research and clinical studies which involved LDL isolation, the researchers have always stressed the necessity to use only freshly isolated LDL, due to the rather quick alterations occurring in the LDL native properties by storage. Thus, for example, to study various immunochemical LDL properties (32), including LDL application as a primary standard for apolipoprotein B measurements by immunochemical assays (11, $19,23)$, to study LDL-receptor activity $(33,34)$, physi$\mathrm{cal}$ and chemical $(35,36)$ as well as other LDL properties it is usually recommended to conduct the experiments using LDL up to 2-4 weeks after their isolation and storage at $4{ }^{\circ} \mathrm{C}$ in the presence of various preservatives. Taking into consideration the labour- and timeconsuming process of LDL isolation and characterization as well as the frequent necessity of using one wellcharacterized portion of LDL, for numerous scientific experiments (for example, in long-term comparative studies) we conclude that the task of long-term LDL storage is a topical and important one.

Aggregation, oxidizing degradation, proteolysis and lipolysis can be major causes for the alterations of native LDL properties occurring during long-term storage. It is obvious that conventional freezing can dramatically decrease the contribution of the latter three processes to LDL denaturation. Nevertheless, according to our electrophoretic data, irreversible formation of aggregated LDL particles occurs upon freezing without an evident apolipoprotein $\mathrm{B}$ fragmentation in these particles in contrast to oxidizing (with $\mathrm{Cu}^{2+}$ ) LDL degradation (37), where, as the authors believe, the generated aggregates present LDL particles cross-linked via apolipoprotein B fragments. The formation of LDL aggregates 
was observed by their intensive vortexing as well (38). It is very likely that the apparent loss of apolipoprotein $B$ immunoreactivity we observed after long-term storage of LDL at $4^{\circ} \mathrm{C}$ (for more than 1 month) and similar losses reported previously $(39,40)$ after LDL freezing and subsequent storage at $-20^{\circ} \mathrm{C}$ can be explained by LDL aggregation. It should also be noted that such apparent losses of apolipoprotein B immunoreactivity were observed only by using "gel" techniques to determine apolipoprotein B: single radial immunodiffusion (39, 40 ), and single radial immunodiffusion and electroimmunoassay in the present study. This conclusion is supported by the known dependence of the "rocket" size upon the size heterogeneity of albumin and haptoglobin (monomers or dimers) when analyzing them by electroimmunoassay (41), as well as by the recently reported data showing the impact of the LDL particles size upon the divergent values between the results of apolipoprotein B determination by single radial immunodiffusion and immunonephelometric assay (42). As we have shown for such LDL samples, where the presence of aggregates was confirmed by non-denaturing gradient polyacrylamide gel electrophoresis with subsequent immunoblotting, the apparent loss of apolipoprotein B immunoreactivity (up to $23 \%$ ) is observed only when "gel" immunochemical techniques (single radial immunodiffusion and electroimmunoassay) are used in contrast to immunoturbidimetric assay.

It is obvious that aggregation of LDL can lead to the alterations not only in immunochemical, but other (physico-chemical, ability to bind with B,E-receptors and etc.) native properties of LDL. The electrophoretic and other data obtained by us show that the degree of aggregation of LDL during low-temperature storage is not dependent as much upon the duration of their storage as directly upon the freeze-thawing process, and dramatically increases (even up to opalescence of the solution and visible precipitation) at multi-fold repetition of the operation. The addition of $1.4 \mathrm{~mol} / \mathrm{l}$ dimethyl sulphoxide prior to freezing of LDL and their subsequent long-term storage at low temperature prevents such LDL aggregation and allows them to maintain their native properties. This conclusion was also confirmed by very recently published data (12), where the authors used sucrose for cryopreservation of LDL. The utilization of bovine serum albumin, HDL, and apolipoprotein A-I, having certain antiaggregatory effect with regard to LDL, to stabilize LDL $(38,40)$ is impossible in many fields of LDL application (for example, by examination of physical and chemical properties of LDL, by obtaining antibodies against apolipoprotein B, etc.). Thus, we have concentrated our efforts on the search for a relevant "cryoprotector", exercising minimal influence upon native LDL properties and allowing alterations in these properties to be avoided during the freeze-thawing process. Among cell cryoprotectors used to preserve such complex biological structures as cells $(13,14)$, we have selected two of the most widely used, i. e. glycerol and dimethyl sulphoxide. Nevertheless, the results of the preliminary experiments on the utilization of glycerol as a cryoprotector to stabilize LDL were negative, leading us to further study the possibility of application of only dimethyl suphoxide to preserve LDL.

The data obtained show that the addition of $1.4 \mathrm{~mol} / \mathrm{l}$ dimethyl sulphoxide directly to the solution of freshly isolated LDL in its high salt buffer and subsequent freezing in accordance with the above method allow $\mathrm{LDL}$ to be stored at $-70^{\circ} \mathrm{C}$ (or preferably in liquid nitrogen) for a considerable period (for up to at least 2 years, and perhaps even longer) without any alterations in their native properties. Moreover, as we also used highly concentrated LDL samples $(10-30 \mathrm{~g} / \mathrm{l}$ by protein), a number of duplicated experiments performed have shown that in many cases (immunochemical apolipoprotein $\mathrm{B}$ determination, LDL binding with B,E-receptors, animal immunization, electrophoretic methods of analysis, electron microscopy, etc.), when LDL are used in a highly diluted state, preliminary dialysis of the "preserved" LDL samples is not necessary. Using $\left[{ }^{125} \mathrm{I}\right] \mathrm{LDL}$ as an example, we have shown the possibility of storage of radiolabelled LDL samples, but in this case the storage time is probably limited by the lifetimes of the relevant radioisotopes. Our observations also strongly suggest that the thermostability of LDL in the presence of $1.4 \mathrm{~mol} / \mathrm{l}$ dimethyl sulphoxide is rather higher ( $A$. B. Sigalov, unpublished data). The absence of significant differences in the properties of the freshly isolated LDL and the LDL preparations cryopreserved according to our methods, as well as the stability of these properties during long-term storage, prove the minimal impact of dimethyl sulphoxide upon the structure and properties of lipoprotein particles, although its destabilizing effect on the secondary protein structure was reported (43).

Thus, the data obtained indicate that dimethyl sulphoxide can be successfully used as a cryoprotector for long-term storage of LDL at low temperature as well as sucrose (12) at least in the applications used. However, it is quite possible that in any particular applications one of them will be preferable. The given methods of LDL cryopreservation may be quite universal with regard to other classes of human lipoproteins and at present we are conducting relevant studies in this direction.

In conclusion we would like to express our hope that the suggested simple and effective technique of LDL storage might find wide application in clinical and biomedical investigations. 


\section{Acknowledgement}

We thank Dr. Ilya Fuki for determination of the LDL ability to bind with B,E-receptors, Olga Melkina for apolipoprotein B mea- surements by electroimmunoassay, Dr. $V . D$. Lotte for electron microscopy and Svetlana Bezruchkina for excellent technical assistance. We wish thank Natalya Pecheritsa for great help in preparing the manuscript.

\section{References}

1. Brown MS, Goldstein JL. A receptor-mediated pathway for cholesterol homeostasis. Science 1986; 232:34-47.

2. The National Institutes of Health Consensus Development Conference. Lowering blood cholesterol to prevent heart disease. J Am Med Ass 1985; 253:2080-6.

3. McGill HC. The pathogenesis of atherosclerosis. Clin Chem 1988; 34:1333-9.

4. Walsh MT, Atkinson D. Calorimetric and spectroscopic investigation of the unfolding of human apolipoprotein B. J Lip Res 1990; 31:1051-62.

5. Glinsburg GS, Walsh MT, Small DM, Atkinson D. Reassembled plasma low density lipoproteins. J Biol Chem 1984; 259:6667-73.

6. Mahley RW, Innerarity $\mathrm{TL}$, Rall SC, Jr, Weisgraber $\mathrm{KH}$. Plasma lipoproteins: apolipoprotein structure and function. $\mathrm{J}$ Lip Res 1984; 25:1277-94.

7. Goldstein JC, Brown MS. Binding and degradation of low density lipoproteins by cultured human fibroblasts. Comparison of cells from a normal subject and from a patients with homozygous familial hypercholesterolemia. J Biol Chem 1988; 263:16842-8.

8. Goldstein JL, Basu SK, Brown MS. Receptor-mediated endocytosis of low density lipoproteins in cultured cells. Methods Enzymol. 1983; 98:241-60.

9. Gherardi E, Hutchings A, Galfre G, Bowyer DE. Rat monoclonal antibodies to rabbit and human serum low-density lipoprotein. Biochem J 1988; 252:237-45.

10. Marcovina S, France D, Phillips RA, Mao SJT. Monoclonal antibodies can precipitate low-density lipoprotein I. Characterization and use in determining apolipoprotein B. Clin Chem 1985; 31:1654-8.

11. Marcovina SM, Albers JJ. Standardization of the Immunochemical Determination of Apolipoproteins A-I and B: A Report on the International Federation of Clinical Chemistry Meeting on Standardization of Apolipoprotein A-I and B Measurements. (Basis for Future Consensus.); Vienna, Austria Apr 18-19, 1989. Clin Chem 1989; 35:2009-15.

12. Rumsey SC, Galeano NF, Arad Y, Deckelbaum RJ. Cryopreservation with sucrose maintains normal physical and biological properties of human plasma low density lipoproteins. J Lip Res 1992; 33:1551-61.

13. Hay RJ. Preservation and characterization. In: Freshney, RI, editor. Animal Cell Culture. A Practical Approach. Washington DC: IRL Press, Oxford, 1986:71-112.

14. Maniatis T, Fritish EF, Sambrook J. Molecular cloning. A laboratory manual. Cold Spring Harbor Laboratory: New York, 1982.

15. Albers JJ, Cabana V, Hazzard W. Immunoassay of human plasma apolipoprotein B. Metabolism 1975; 24:1339-51.

16. Laemmli UK. Cleavage of structural proteins during the assembly of the head of bacteriophage T4. Nature 1970; 227:680-5.

17. Ouchterlony $\mathrm{O}$. Handbook of immunodiffusion and immunoelectrophoresis. Ann Arbor: Ann Arbor Science Publishers, Michigan, 1963:21-31.

18. Lowry OH, Rosebrough NJ, Farr AL, Randall RJ. Protein measurement with the Folin phenol reagent. J Biol Chem 1951; 193:265-75.

29. Albers JJ, Lodge MS, Curtiss LK. Evaluation of a monoclonal antibody-based enzyme-linked immunosorbant assay as a candidate reference method for the measurement of apolipoprotein B-100. J Lip Res 1989; 30:1445-58.
20. Anderson RL, Davis S. An organic phosphorus assay which avoids the use of hazardous perchloric acid. Clin Chim Acta 1982; 121:111-6.

21. McFarlane AS. Efficient trace labeling of proteins with iodine. Nature (London) 1958; 182:43-4.

22. Bilheimer DW, Eisenberg S, Levy RL. The metabolism of very low density lipoprotein proteins. I. Preliminary in vitro and in vivo observations. Biochim Biophys Acta 1972; 212-21.

23. Durrington PN, Whicher JT, Warre $\mathrm{C}$, Bolton $\mathrm{CH}$, Hartog $\mathrm{M}$. A comparison of methods for the immunoassay of serum apolipoprotein B in man. Clin Chim Acta 1976; 71:95-108.

24. Ordovas JM, Peterson JP, Santaniello P, Cohn JS, Wilson PWF, Schaefer EJ. Enzyme-linked immunosorbent assay for human plasma apolipoprotein B. J Lip Res 1987; 28:1216-24.

25. Krauss RM, Burke DJ. Identification of multiple subclasses of plasma low density lipoproteins in normal humans. J Lip Res 1982; 23:97-104.

26. Towbin H, Staehelin T, Gordon J. Electrophoretic transfer of proteins from polyacrylamide gels to nitrocellulose sheets: procedure and some applications. Prov Natl Acad Sci USA 1979; 76:4350-4.

27. Bailyes EM, Richardson PJ, Luzio JP. Immunological methods applicable to membranes. In: Findlay JBC, Evans WH, editors. Biological membranes. A practical approach. Washington DC: IRL Press, Oxford, 1987:73-101.

28. Laurell CB. Quantitative estimation of proteins by electrophoresis in agarose gel containing antibodies. Anal Biochem $1966 ; 15: 45-52$.

29. Curry MD, Gustafson A, Alaupovic P, McConathy WJ. Electroimmunoassay, radioimmunoassay, and radial immunodiffusion assay evaluated for quantification of human apolipoprotein B. Clin Chem 1978; 24:280-6.

30. Rifai N, King ME. Immunoturbidimetric assay of apolipoproteins A, AI, AII and B in serum. Clin Chem 1986; 32:957-61.

31. Forte TM, Nordhausen RW. Electron microscopy of negatively stained lipoproteins. Methods Enzymol 1986; 128:442-57.

32. Schumaker VN, Robinson MT, Curtiss LK, Butler R, Sparkes RS. Anti-apolipoprotein B monoclonal antibodies detect human low density lipoprotein polymorphism. J Biol Chem 1984; 259:6423-30.

33. Aviram M, Lunk-Katz S, Phillips MC, Chait A. The influence of the triglyceride contents of low density lipoprotein on the interaction of apolipoprotein B-100 with cells. J Biol Chem $1988 ; 263: 16842-8$.

34. Weisgraber KH, Innerarity TL, Mahley RW. Role of the lysine residues of plasma lipoproteins in high affinity binding to cell surface receptors on human fibroblasts. J Biol Chem 1978; 253:9053-62.

35. Tilley L, Sawyer WH, Morrison JR, Fidge NH. Rotational diffusion of human lipoproteins and their receptors as determined by time-resolved phosphorescence anisotropy. J Biol Chem 1988; 263:17541-7.

36. Goormaghtigh E, De Meutter J, Vanloo B, Brasseur R, Rosseneu M, Ruysschaert JM. Evaluation of the secondary structure of apo B-100 in low-density lipoprotein (LDL) by infrared spectroscopy. Biochim Biophys Acta 1989; 1006:147-50.

37. Zawadzki Z, Milner RW, Marcel YL. An immunochemical marker of low density lipoprotein oxidation. J Lip Res 1989; 30:885-91.

38. Khoo JC, Miller E, McLoughlin P, Steinberg D. Prevention of low density lipoprotein aggregation by high density lipoprotein or apolipoprotein A-I. J Lip Res 1990; 31:645-52. 
39. Steele JCH, Jr, Reynolds JA. Characterization of the apolipoprotein B polypeptide of human plasma low density lipoprotein in detergent and denaturant solutions. J Biol Chem 1979; 254:1633-8.

40. Havekes L. Apparent loss of apolipoprotein B immunoreactivity of isolated low density lipoprotein during storage: consequences for quantification of apolipoprotein $B$ in human plasma. Clin Chim Acta 1981; 116:131-5.

41. Laurell CB. Electroimmuno assay. Scand J Clin Lab Invest 1972; 29:21-37.

42. Zhao SP, Smelt AHM, Leuven JAG, van't Hooft FM, Hollaar L, Serree JMP, van der Laarse A. Influence of low-density- lipoprotein particle size on measurement of apolipoprotein B Clin Chem 1991; 37:1139.

43. Jackson M, Mantsch HH. Beware of proteins in DMSO. Biochim Biophys Acta 1991; 1079:231-5.

Dr. Alexander B. Sigalov Department of Biomedical R \& D, AMW Co Ltd. 22-1-11 Tarusskaya Street Moscow 117588

Russia 


$$
.1
$$

